\title{
310PENGEMBANGAN MODEL PEMBELAJARAN KOOPERATIF TUTOR TEMAN SEBAYA SETTING NYANTRIK DENGAN ASESMEN FORMATIF BENTUK KINERJA UNTUK MATA PELAJARAN TEKNIK GAMBAR MANUFAKTUR DI KELAS XI TPm-1 SMK NEGERI 3 SINGARAJA
}

\author{
Oleh \\ Komang Agus Widhyasa, I Made Candiasa, I Gede Sudiartha \\ Program Studi Penelitian Dan Evaluasi Pendidikan, Program Pascasarjana \\ Universitas Pendidikan Ganesha \\ Singaraja, Indonesia
}

e-mail: (agus.widhyasa, made.candiasa, gede.sudirtha)@undiksha.ac.id

\begin{abstract}
Abstrak
Tujuan penelitian ini adalah mengembangkan model pembelajaran Kooperatif Tutor Teman Sebaya (TTS) setting nyantrik yang valid dan praktis disertai dengan asesmen formatif bentuk kinerja. Pengembangan menggunakan model $4 \mathrm{D}$ yang meliputi define, design, dan develop. Penelitian ini tidak dikembangkan pada skala yang lebih luas, baik di kelas lain, sekolah lain. Model sudah diuji terbatas di kelas XI TPm 1 SMKN 3 Singaraja untuk memperoleh hasil validasi dan kepraktisannya. Hasil validasi model pembelajaran terdiri atas sintak, sistem sosial, prinsip reaksi, sistem pendukung, dan dampak instruksional dan pengiring. Sintak model pembelajaran terdiri dari tujuan dan motivasi, informasi materi, mengorgansasi siswa ke dalam kelompok-kelompok belajar, diskusi kelompok secara nyantrik, laporan kelompok, penghargaan, kesimpulan pembelajaran, tes/evaluasi pembelajaran. Hasil validasi dengan kategori validitas tinggi. Sedangkan melalui uji coba lapangan diproleh tingkat kepraktisan respon siswa sebesar $80 \%$ dengan katagori praktis dan respon kepraktisan guru sebesar $87 \%$ dengan katagori sangat praktis.
\end{abstract}

Kata kunci: asesmen, model pembelajaran kooperatif, nyantrik, pengembangan, tutor teman sebaya.

\begin{abstract}
This study aimed at developing cooperative learning method by using nyantrik setting of peer tutor strategy for validity and practicability need supported by the steps of performace formative assessment. . The development used 4D model which included define, design, and develop. It's not tested at other and other class. This model had limitedly tested at XI Mechanical Engineering 1 Class of SMK Negeri 3 Singaraja. It was consisted of syntax, social system, principal of reaction, supportive system, and instructional effects and escorts. Syntax composed motivation and porpose, informations study, create a group, group discussion, grpoup report, reward, conclusion, andd evaluations. The result of the validity shows with a high validity category. The result of the practicability from class trials shows that the students' practicability reaches practical category with the number of $80 \%$ and teacher responses very practical category with the number of $87 \%$
\end{abstract}


Keywords: assessment, cooperative learning method, development, nyantrik, peer tutor.

\section{PENDAHULUAN}

Sekolah Menengah Kejuruan (SMK) adalah salah satu bentuk satuan pendidikan formal yang menyelenggarakan pendidikan kejuruan pada jenjang pendidikan menengah sebagai lanjutan dari SMP, MTs, atau bentuk lain yang sederajat atau lanjutan dari hasil belajar yang diakui sama atau setara SMP atau MTs. (PP no. 66 tahun 2010). Undang-Undang Sistem Pendidikan Nasional no. 20 tahun 2003 pasal 15 ayat 3 menjelaskan bahwa pendidikan kejuruan merupakan pendidikan menengah yang mempersiapkan peserta didik terutama untuk bekerja dalam bidang tertentu. Dari pengertian di atas diketahui bahwa kompetensi lulusan harus memiliki kemampuan yang mencakup sikap, pengetahuan, dan keterampilan. Lulusan SMK diharapkan mampu bekerja sesuai dengan bidang keahliannya masingmasing. Namun pada kenyataan menunjukkan bahwa lulusan SMK justru banyak yang menganggur.

$$
\text { Dalam upaya optimalisasi }
$$

kompetensi lulusan, penentuan model pembelajaran yang tepat sangat krusial. Memang sudah banyak model pembelajaran yang dikembangkan, namun belum tentu relevan dengan proses pembelajaran di SMK. Dalam kesempatan seperti ini, sangat tepat kiranya untuk mengkaji model pembelajaran berbasis budaya lokal yang sudah terbukti mampu mewariskan kompetensi di bidang keterampilan dari satu generasi ke generasi berikutnya. Sebagai contoh di Bali misalnya, pendidikan nyantrik sudah mampu membelajarkan keterampilan seni tari, seni tabuh, seni lukis, seni bangunan, dan seni lainnya.

Pola ajar nyantrik menularkan ilmu atau keahlian melalui pewarisan langsung dalam kehidupan sehari-hari. Oleh karena itu, dalam proses nyantrik, cantrik (murid) selalu mengikuti semua kegiatan gurunya dan termasuk mengikuti gurunya kemanapun pergi. Tujuan utamanya adalah dapat belajar ilmu atau keahlian yang diingiinkan dari gurunya. Pendidikan atau pembelajaran dengan setting nyantrik memang masih terjadi dalam beberapa bidang. Namun, perubahan zaman yang diikuti pola hidup membuat penerapan pembelajaran dengan setting nyantrik yang kental seperti dulu sulit dilakukan

$$
\text { Konsep }
$$

pengembangan

pembelajaran berbasis budaya akan diterapkan dalam penggabungan pembelajaran kooperatif TTS dengan nyantrik. Sistem nyantrik Apabila dikaitkan dengan perkembangan kurikulum yang berlaku saat ini yaitu kurikulum 2013 sangat signifikan. Penerapan unsur nyantik dapat berpengaruh dalam meningkatkan segi pemahaman hingga keterampilan siswa. tingkatan pemahaman siswa berupa ranah kognitif sebagai mana yang tertera dalam taksonomi bloom yang meliputi mengingat, memahami, mengaplikasi, menganalisis, mengevaluasi, dan mencipta. Dalam tingkatan keterampilan pada ranah psikomotorik berupa meniru, manipulasi, presisi, artikulasi dan naturalisasi.

Dalam kegiatan pembelajaran 2013, siswa akan dituntut dengan kegiatan pembelajaran yang lebih dikenal dengan $5 \mathrm{M}$ yaitu, mengamati, menanya, mengumpulkan data, mengasosiasi, dan mengkomunikasikan. Contoh esensi dari kegiatan mengamati berupa siswa akan belajar secanya nyantrik dengan cara mengamati tutor baik dari segi prilaku dan cara belajar dalam proses pembelajaran. Esensi menanya berupa seluruh anggota kelompok mengajukan pertanyaan secara aktif dan mandiri tentang pembelajaran kepada tutor seputar masalah pelajaran. Esensi mengumpulkan data yang terkait pembelajaran sebagai mana tata cara yang dilakukan oleh tutor. Dengan kata lain siswa akan mengumpulkan seluruh informasi sesuai teknik yang sudah dipelajari secara nyantrik dari tutor. Esensi mengasosiasi berupa siswa akan mengkatagorikan data dari mengumpulkan data sesuai arahan tutor. Dan sebagai contoh esensi dari mengkomunikasikan berupa bagaimana siswa menyampaikan kesimpulan 
pembelajaran dari proses pembelajaran yang telah dilakukan secara nyantrik

Dalam penerapan pembelajaran setting nyantrik akan didukung dengan asesmen formatif bentuk kinerja. Penilaian dalam asesmen bentuk kinerja merupakan salah satu bentuk penilaian yang mencoba melihat kompetensi siswa tidak hanya dari segi kognitif saja, akan tetapi dilihat dari sudut pandang psikomotorik siswa. Maksud dari asesmen formatif adalah evaluasi yang dilaksanakan di tengah-tengah atau pada saat berlangsungnya proses pembelajaran, yaitu dilaksanakan pada setiap kali satuan pembelajaran atau subpokok bahasan dapat diselesaikan dengan tujuan untuk mengetahui sejauh mana peserta didik "telah terbentuk" sesuai dengan tujuan pengajaran yang telah ditentukan

\section{TIPE ARTIKEL}

Slavin (2005), Mengemukakan model pembelajaran sebagai suatu acuan kepada suatu pendekatan pembelajaran termasuk tujuan, sintaksnya, lingkungan dan sistem pengelolaannya. . Sedangkan menurut Nini Subini (2012:102), Model pembelajaran merupakan cara yang dilakukan dalam proses pembelajaran untuk mencapai hasil yang maksimal. Model pembelajaran dapat berisi unsur dan tujuan pembelajaran, kegiatan belajar, kegiatan/aktivitas belajar antara guru, murid dan perangkat belajar serta dampak/hasil dari kegiatan belajar tersebut. Dari beberapa pengertian di atas maka dapat disimpulkan bahwa model pembelajaran diartikan sebagai prosedur sistematis dalam mengorganisasikan pengalaman belajar untuk mencapai tujuan belajar.

Slavin (2005), Pembelajaran kooperatif (cooperatif learning) adalah suatu strategi pembelajaran yang menekankan pada sifat atau prilaku bersama dalam bekerja atau membantu antar sesama dalam struktur kerja sama yang teratur pada kelompok yang terdiri atas dua orang atau lebih. Keberhasilan kerja sama dipengaruhi oleh keterlibatan anggota kelompok itu sendiri. Pembelajaran kooperatif dikembangkan dari pemikiran, nilai-nilai demokrasi, belajar aktif, perilaku kerjasama, dan menghargai pluralisme dalam masyarakat yang multikultural. Metode pembelajaran kooperatif terbagi menjadi beberapa macam yang meliputi Student Team-Achievement Division (STAD), Team Games Turnamen (TGT), Jigsaw II, Team Acclarated Intruction (TAI), Cooperatif Integrated Reading Composition (CIRC, danTutor Teman Sebaya.(TTS)

Aria Djalil (1997:38) menuliskan bahwa "pengertian tutor sebaya adalah seorang siswa pandai yang membantu belajar siswa lainnya dalam tingkat kelas yang sama". Sedangkan menurut Arikunto (1986:77) bahwa tutor sebaya adalah seseorang atau beberapa orang siswa yang ditunjuk oleh guru sebagai pembantu guru dalam melakukan bimbingan terhadap kawan sekelas. Sedangkan Nurita Putranti (2007:02) mengemukakan "tutor sebaya adalah siswa di kelas tertentu yang memiliki kemampuan di atas rata-rata anggotanya yang memiliki tugas untuk membantu kesulitan anggota dalam memahami materi belajar". Berdasarkan berbagai pendapat di atas dapat di simpulkan bahwa pembelajaran tutor sebaya adalah pembelajaran dimana siswa yang lebih pandai dari temanya membantu dan mengajari teman lain yang belum bisa terhadap suatu materi.

Pembelajaran berbasis budaya merupakan strategi penciptaan lingkungan belajar dan perancangan pengalaman belajar yang mengintegrasikan budaya Sardjiyo dan Pannen (2005). Sedangkan menurut Banks \& Banks (2005) bahwa segala sesuatu yang terjadi dalam pendidikan berkaitan dengan budaya, baik dalam hal pengakuan, transforasinya, maupun penciptaanya. Dalam hal ini, budaya menjadi sebuah media bagi siswa untuk mentransformasikan hasil observasi mereka ke dalam bentuk prinsip- prinsip yang kreatif tentang alam.

Nyantrik berasal dari kata dasar cantrik. Cantrik adalah istilah dalam bahasa Jawa yang berarti orang yang berguru kepada orang pandai, sakti; murid seorang pendeta atau pertapa; istilah Cantrik kemudian berkembang arti menjadi pengikut. Dalam kamus besar bahasa 
Indonesia disebutkan bahwa nyantrik dapat berarti orang yang berguru kepada orang pandai (sakti). Memang dahulu kala nyantrik diterapkan oleh orang-orang yang ingin belajar ilmu keagamaan, ilmu kanuragan, atau Imu lainnya dari guru, pendeta atau pertapa.

Menurut Trespeces (Depdiknas 2003), Performance Assessment adalah berbagai macam tugas dan situasi dimana peserta tes diminta untuk mendemonstrasikan pemahaman dan mengaplikasikan pengetahuan yang mendalam, serta keterampilan di dalam berbagai macam konteks sesuai dengan kriteria yang diinginkan. Asesmen ini diterapkan dalam mata pelajaran Teknik Gambar Manufaktur. Sedangkan teori tentang pembelajaran Teknik Gambar Manufaktur disampaikan oleh Agus Suprijono (2009:13) Pembelajaran teknik gambar manufaktur yang dilakukan di sekolah dibantu oleh software/aplikasi menggambar di komputer, Autodeks Inventor adalah aplikasi yang dikeluarkan Autodeks yang dapat digunakan untuk menggambar 2D dan 3D di komputer. Selain itu, dengan menggunakan software Autodesk diharapkan mampu mewujudkan ketercapaian pembelajaran yang diinginkan. Ketercapaian tujuan pembelajaran dapat dilihat pada tingkat pencapaian kompetensi yang dihasilkan oleh peserta didik. Untuk mengetahui ketercapaian kompetensi dalam sebuah pelajaran dapat dilihat dari tiga aspek yaitu pengetahuan (kognitif), sikap (afektif) dan keterampilan (psikomotorik).

Pengaplikasian pembelajaran setting nyantrik akan ditopang dengan model pembelajaran kooperatif strategi tutor teman sebaya. Pembelajaran kooperatif sendiri muncul karena adanya perkembangan dalam sistem pembelajaran yang ada. Pembelajaran kooperatif menggantikan sistem pembelajaran yang individual. Pembelajaran kooperatif ini membuat siswa dapat bekerjasama dan adanya partisiasi aktif dari siswa. Guru sebagai fasilisator dan pembimbing yang akan mengarahkan setiap peserta didik menuju pengetahuan yang benar dan tepat.
Sedangkan Tutor Sebaya dikenal dengan pembelajaran teman sebaya atau antar peserta didik, hal ini bisa terjadi ketika peserta didik yang lebih mampu menyelesaikan pekerjaan sendiri dan kemudian membantu peserta didik lain yang kurang mampu.

Penerapan sistem nyantrik pada pembelajaran kooperati tipe tutor teman sebaya akan dilakukan melalui penggabungan sintak dari masing-masing komponen tersebut.

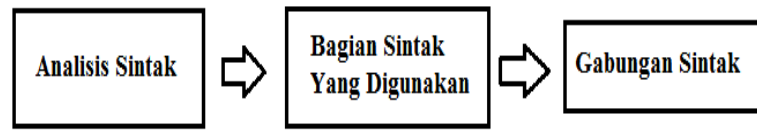

Gambar 1. Alur Pembentukan Sintak Baru

Setiap sintak pada masing-masing komponen akan mewakili pembentukan sintak model pembelajaran yang baru. Adapun masing-masing bagian dari sintak yang akan digunakan sebagai berikut:

Tabel 1. Penjabaran Sintak yang Dipergunakan.

\begin{tabular}{|c|c|c|}
\hline $\begin{array}{l}\text { Pembelajaran } \\
\text { Kooperatif }\end{array}$ & $\begin{array}{c}\text { Tutor } \\
\text { Teman } \\
\text { Sebaya }\end{array}$ & $\begin{array}{c}\text { Pembelajaran } \\
\text { Nyantrik }\end{array}$ \\
\hline $\begin{array}{l}\text { Tujuan dan } \\
\text { Motivasi }\end{array}$ & $\begin{array}{l}\text { Diskusi } \\
\text { kelompok }\end{array}$ & \multirow{4}{*}{$\begin{array}{l}\text { Nyantrik } \\
\text { dilakukan oleh } \\
\text { orang yang } \\
\text { ingin memiliki } \\
\text { keahlian khusus } \\
\text { (anggota } \\
\text { kelompok) } \\
\text { kepada orang } \\
\text { yang lebih } \\
\text { berpengalaman } \\
\text { di bidang } \\
\text { tersebut (Tutor } \\
\text { Kelompok) }\end{array}$} \\
\hline Informasi & $\begin{array}{l}\text { Laporan } \\
\text { Tim }\end{array}$ & \\
\hline $\begin{array}{l}\text { Mengorganisasi } \\
\text { Kelompok }\end{array}$ & Kesimpulan & \\
\hline $\begin{array}{l}\text { Reward/ } \\
\text { Penghargaan }\end{array}$ & $\begin{array}{l}\text { Tes/ } \\
\text { Evaluasi }\end{array}$ & \\
\hline
\end{tabular}

Strategi pembelajaran yang teratur pada kelompok yang berfungsi membantu peserta didik yang kurang mampu agar mudah memahami pelajaran, peserta didik yang kurang aktif menjadi aktif karena tidak malu lagi untuk bertanya dan mengeluarkan pendapat secara bebas. Dalam setiap kelompok terdapat tutor yang diharapkan dapat membantu temannya dalam proses pembelajaran. Dalam proses ini anggota kelompok akan belajar secara nyantrik terhadap tutornya. Maka dapat dipahami adanya kebiasaan peserta didik untuk 
saling belajar kepada teman (tutor) akan terjadi keakraban yang akhirnya akan memberikan pemahaman yang lebih mendalam mengenai materi yang sedang dipelajari terutama bagi siswa yang mengalami kesulitan dalam belajar.

\section{METODE PENELITIAN}

Penelitian ini menggunakan jenis penelitian dan pengembangan (Research and Development) dengan metode pengumpulan data berupa validasi, observasi, serta studi dokumentasi. Metode penelitian menggunakan model 4-D yang dikembangkan oleh Thiagarajan. Metode dan model ini dipilih karena bertujuan untuk menghasilkan produk yang dikembangkan kemudian diuji kelayakannya. Subjek penelitian adalah kelas XI TPm-1 SMK Negeri 3 Singaraja yang berjumlah 30 orang siswa. Penelitian dilaksanakan pada 1 tahun semester ajaran 2017/2018.. Adapun alur pengumpulan data yang dilakukan dalam penelitian ini adalah sebagai berikut:

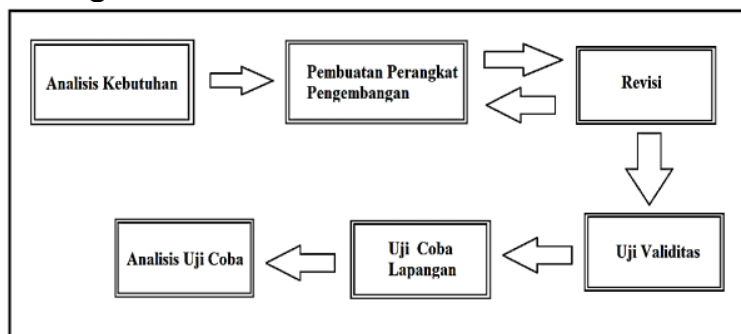

Gambar 2. Langkah pengumpulan data

Digunakan dua macam instrumen dalam penelitian ini yaitu, instrumen validitas dan instrumen angket.

Validitas dilakukan dengan memaparkan hasil model pembelajaran yang kemudian di nilai dengan instrumen pengembangan. Dari hasil validasi dengan dua orang ahli, diperoleh hasil kesimpulan relevan dan tingkat validitasnya sangat tinggi sehingga dapat dipergunakan pada kegiatan pembelajaran selanjutnya. Menetukan koefisien validitas isi, hasil penialaian dari kedua pakar dimasukkan ke dalamtabulasi silang $2 \times 2$ yang terdiri dari kolom A, B, C, dan D. Analisis dengan menggunakan perhitungan menurut Gregory sebagai berikut.

Tabel 2. Tabulasi Silang 2x2 Gregory

\begin{tabular}{ccc}
\hline & \multicolumn{2}{c}{ Penilai I } \\
\cline { 2 - 3 } Penilai 2 & $\begin{array}{c}\text { Kurang } \\
\text { Relevan }\end{array}$ & Relevan \\
\hline $\begin{array}{c}\text { Kurang } \\
\text { Relevan }\end{array}$ & A & C \\
\hline Relevan & B & D \\
\hline
\end{tabular}

Validitas isi dihitung dengan rumus berikut.

$$
V I=\frac{D}{A+B+C+D} \operatorname{dimana} V I=\text { validitas isi }
$$

Untuk menyimpulkan hasilnya menggunakan kriteria seperti yang dapat dilihat pada Tabel 4 sebagai berikut:

Tabel 3. Batasan Koefisian Validasi

\begin{tabular}{cc}
\hline $\begin{array}{c}\text { Batasan Koefisian } \\
\text { Validasi }\end{array}$ & Kriteria \\
\hline $0-0,19$ & $\begin{array}{c}\text { Derajat validitas } \\
\text { sangat rendah }\end{array}$ \\
\hline $0,20-0,39$ & $\begin{array}{c}\text { Derajat validitas } \\
\text { rendah }\end{array}$ \\
\hline $0,40-0,59$ & $\begin{array}{c}\text { Derajat validitas } \\
\text { sedang }\end{array}$ \\
\hline $0,60-0,89$ & Derajat validitas tinggi \\
\hline $0,90-1,00$ & $\begin{array}{c}\text { Derajat validitas } \\
\text { sangat tinggi }\end{array}$ \\
\hline
\end{tabular}

Untuk memberikan makna dan keputusan pada saat uji coba dalam bentuk angket, maka digunakan tabel konversi tingkat pencapaian dengan skala seperti pada tabel.

Tabel 4. Konversi Tingkat Pencapaian

\begin{tabular}{ccc}
\hline $\begin{array}{c}\text { Tingkat } \\
\text { Pencapaian (\%) }\end{array}$ & Kualifikasi & Keterangan \\
\hline $85-100$ & $\begin{array}{c}\text { Sangat } \\
\text { praktis }\end{array}$ & $\begin{array}{c}\text { Tidak perlu } \\
\text { direvisi }\end{array}$ \\
\hline $75-84$ & Praktis & $\begin{array}{c}\text { Tidak perlu } \\
\text { direvisi }\end{array}$ \\
\hline $65-74$ & $\begin{array}{c}\text { Cukup } \\
\text { praktis }\end{array}$ & Direvisi \\
\hline $55-64$ & Kurang & Direvisi \\
\hline $0-54$ & $\begin{array}{l}\text { Sangat } \\
\text { kurang }\end{array}$ & Direvisi \\
\hline
\end{tabular}

Tujuan dari perhitungan ini adalah untuk mengetahui tingkatan respon siswa dan guru setelah melakukan kegiatan 
pembelajaran kooperatif strategi TTS setting nyantrik. Adapun perhitungan dilakukan berupa menentukan jumlah pilihan responden dari tiap indikator dan menentukan interval dan persentase.

\section{HASIL DAN PEMBAHASAN}

Hasil analisis data validasi instrumen penelitian, komponen model pembelajaran Kooperatif TTS Setting Nyantrik, RPP dan PHB diketahui bahwa model yang dikembangkan telah memenuhi kriteria valid. Berdasarkan penilaian dari ahli tingkat validasi komponen model pembelajaran kooperatif TTS setting nyantrik yang terdiri atas sintak, sistem sosial, prinsip reaksi dan dampak instruksional dan pengiring mencapai kriteria sangat valid. Selanjutnya, tingkat Validasi perangkat pendukung pembelajaran ditunjukkan oleh Validasi RPP mencapai kriteria sangat valid dan PHB asesmen formatif mencapai kriteria sangat valid. Sedangkan tingkat kepraktisan model pembelajaran melalui angket respon guru dengan kriteria sangat praktis, dan respon siswa dengan kriteria praktis. Berikut ini secara ringkashasil pengembangan yang dilakukan.

Tabel 5. Hasil Pengembangan

\begin{tabular}{|c|c|c|}
\hline Nama & Nilai & Kriteria \\
\hline $\begin{array}{l}\text { Instrumen } \\
\text { Pengembangan }\end{array}$ & 1.00 & $\begin{array}{c}\text { Validitas } \\
\text { Sangat tinggi }\end{array}$ \\
\hline $\begin{array}{l}\text { Rancangan Model } \\
\text { Pembelajaran } \\
\text { Kooperatif TTS } \\
\text { setting nyantrik }\end{array}$ & 1.00 & $\begin{array}{c}\text { Validitas } \\
\text { Sangat tinggi }\end{array}$ \\
\hline $\begin{array}{l}\text { Rancangan Rencana } \\
\text { Pelaksanaan } \\
\text { Pembelajaran (RPP) }\end{array}$ & 1.00 & $\begin{array}{c}\text { Validitas } \\
\text { Sangat tinggi }\end{array}$ \\
\hline $\begin{array}{l}\text { Rancangan Penilaian } \\
\text { Hasil Belajar (PHB) } \\
\text { Asesmen Formatif }\end{array}$ & 1.00 & $\begin{array}{c}\text { Validitas } \\
\text { Sangat tinggi }\end{array}$ \\
\hline $\begin{array}{l}\text { Keperktisan Guru } \\
\text { (respon) }\end{array}$ & $87.3 \%$ & Sangat Praktis \\
\hline Keperaktisan Siswa & $80.8 \%$ & Praktis \\
\hline $\begin{array}{l}\text { Keterlaksanaan } \\
\text { Komponen Model } \\
\text { Pembelajaran } \\
\text { (sintak, sistem sosial, } \\
\text { dampak intruksional } \\
\text { dan pengiring) }\end{array}$ & $100 \%$ & $\begin{array}{l}\text { Terlak-sana } \\
\text { Seluruhnya }\end{array}$ \\
\hline
\end{tabular}

Berdasarkan Tabel 5, disimpulkan bahwa keseluruhan instrumen telah memenuhi kriteria relevan untuk digunakan. secara umum hasil penilaian kelayakan (validasi ahli) menunjukkan bahwa rancangan model pembelajaran, RPP dan PHB layak digunakan.

Pengembangan model pembelajaran kooperatif TTS setting nyantrik dalam penelitian ini mengadaptasi prosedur pengembangan adalah pengembangan model 4-D yang dikembangkan oleh Thiagarajan. Metode dan model ini dipilih karena bertujuan untuk menghasilkan produk Produk yang dikembangkan kemudian diuji kelayakannya dengan validitas dan uji coba produk milik Gregory untuk mengetahui sejauh mana pembelajaran setting nyantrik berpengaruh terhadap pembelajaran di dalam kelas.

Berikut ini akan dipaparkan secara jelas mengenai gabungan dari hasil pengembangan model pembelajaran melalui kevalidan dan kepraktisan dengan hubungan model pembelajaran dengan hasil penelitian yang relevan.

Model pembelajaran kooperatif TTS setting nyantrik yang dikembangkan ini telah memenuhi kriteria valid, dan telah direvisi sesuai dengan saran dari ahli. Sehingga dapat dipergunakan pada kegiatan pembelajaran selanjutnya. Dalam rancangan model pembelajaran kooperatif setting nyantrik yang sudah divalidasi, model pembelajaran kooperatif memiliki sintak sebagai berikut : 1) Tujuan dan Motivasi. Pada langkah ini guru menjelaskan tujuan pembelajaran dan pemberian motivasi bagi siswa. 2) Informasi Materi. Tahap ini berupa penyampaian materi yang akan menjadi topik bahasan secara kelompok. 3) Mengorgansasi Siswa ke dalam Kelompok-kelompok Belajar. Pada tahap ini berupa pembagian kelompok siswa sebelum kegiatan diskusi berlangsung. 4) Diskusi Kelompok Secara Nyantrik, dalam Kegiatan Diskusi Kelompok. Para tutor bertangggung jawab dalam pemahaman materi yang dikuasai oleh siswa. Seluruh siswa berdiskusi mengenai topik bahasan dari mata pelajaran teknik gambar manufaktur. Pada 
kesempatan ini, sumber materi disampaikan langsung oleh masing-masing tutor kepada anggota kelompoknya. Tutor akan menjelasakan dan mendemonstrasikan tata cara menggambar menggunakan TIK dalam teknik gambar manufaktur, sedangkan anggota kelompok akan belajar secara nyantrik mengikuti tutor dalam proses menggambar. Anggota kelompok akan mengikuti tahapan-tahapan cara menggambar yang akan diberikan oleh tutornya. Dalam proses ini, kegiatan guru hanyalah mengawasi dan membantu apabila terjadi kesulitan dalam kelompok. Kegiatan seperti iniakan berlangsung ini hingga proses diskusi selesai. 5) Laporan Kelompok. Dalam pembelajaran kelompok berupa penyampaian hasil diskusi yang delah dilakukan. 6) Penghargaan. Penghargaan yang dilakukan berupa pemberiah hadiah bagi kelompok terbaik dalam presentasi. 7) Kesimpulan pembelajaran. Kesimpulan pembelajaran dilakukan guru setiap saat akhir pelajaran. Inti dari kesimpulan ini berupa permasalahan siswa yang dialami saat proses pembelajaran. 8) Tes/Evaluasi Pembelajaran. Evaluasi dilakukan untuk memperoleh kesimpulan akhir pembelajaran.

Dalam penelitian ini, uji coba lapangan dilakukan dengan mengimplementasikan model pembelajaran kooperatif TTS setting nyantrik di sekolah. Dari data uji coba yang dilakukan, respon siswa yang dinilai meliputi indikator dalam penilaian penggunaan model pembelajaran seperti mudah dipahami, mudah digunakan, berpengaruh terhadap motivasi, dan kepuasan alam penggunaan. Dari ujicoba yang dilakukan kepada siswa diperoleh hasil respon dengan tingkat kepraktisan praktis.

Dalam uji coba untuk mengetahui tingkat kepraktisan melalui respon guru menggunakan indikator yang meliputi kepuasan dalam menggunakan model pembelajaran kooperatif TTS setting nyantrik. Dari hasil uji coba lapangan diperoleh tingkat kepraktisan dari guru dengan kriteria sangat praktis. $\begin{array}{ccc}\text { Dalam } & \text { pengembangan } \\ \text { pembelajaran } & \text { yang } & \begin{array}{c}\text { model } \\ \text { dilakukan }\end{array}\end{array}$ menggunakan dua teknik pengambilan keputusan. Pertama dengan memvalidasi rancangan model pembelajaran. Kedua membandingkan rancangan model pembelajaran dengan penelitian yang relevan. Hasil perbandingan dengan penelitian yang relevan, pada bagian konsep pembelajaraan kooperatif , dilakukan pembanding pada penelitian oleh Aceng Jaelani (2013), dan I Ketut Tastra (2013). Pada hasil penelitian membuktikan bahwa persamaan pembelajaran basis kelompok memiliki kesamaan dalam mengatasi permasalahan seputar pembelajaran khususnya dalam hasil belajar. Contoh penelitian di atas dapat disimpulkan bahwa unsur pembelajaran kooperatif memiliki pengaruh apabila diterapkan dalam pembalajaran yang lain.

Pembanding yang lain dilakukan pada penelitian milik Adib Wahyu Hidayat (2013), dari hasil penelitian tersebut dapat disimpulkan bahwa pembelajaran TTS dapat meningkatkan kompetensi siswa. Dengan demikian peran pembelajaran dengan konsep TTS secara tidak langsung dapat meningkatkan kompetensi siswa baik dari dari segi pemahaman serta keterampilan. Melihat hasil kesimpulan tersebut model pembelajaran kooperatif TTS secara tidak langsung sangat relevan apabila diterapkan sebagai model pembelajaran di sekolah. Apalagi digunakan dalam upaya peningkatan pengetahuan dan keterampilan menggambar siswa.

Pembanding lain dalam pembelajaran berbasis budaya dilakukan pada penelitian pembelajaran nyantrik dilakukan oleh Aprilina Eka Fitriani (2013) dan Haryono (2016), hasil penelitian tersebut menyebutkan bahwa pengaruh pembelajaran nyantrik memberi dampak terhadap peningkatan kemampuan peserta didik melalui pembelajaran berbasis kearifan lokal. Pada penelitian tersebut, efek budaya nyantrik yang timbul juga berlangsung di luar proses pembelajaran. Siswa yang menerima treatmen dari pembelajaran kooperatif TTS setting 
nyantrik melalui melihat, mendengar, menirukan atau praktik mampu berinteraksi sosial dengan baik dengan sesama. Bahkan dalam dunia pendidikan, pembelajaran nyantrik dapat membentuk siswa seperti semboyan Kihajar Dewantara yaitu Ing ngarsa sung tuladha, ing madya mangun karsa, and tut wuri handayani. Dengan demikian, pembelajaran kooperatif TTS dengan unsur nyantrik sangat relevan diterapkan di dalam pembelajaran di sekolah. Salain mampu meningkatkan pemahaman dan keterampilan, unsur nyantrik juga dapat menciptakan sikap spiritual dan sosial peserta didik sesuai tuntutan kurikulum yang berlaku.

Pelaksanaan proses pembelajaran kooperatif TTS setting nyantrik, penilaian hasil belajar nantinya akan dirancang menggunakan asesmen formatif bentuk kinerja. Sebagai pertimbangan, pembanding dalam rencana penggunaan, dilakukan pembanding dalam penerapan asesmen formatif bentuk kinerja milik Sukawijana (2015), dari hasil penelitian tersebut dapat disimpulkan asesmen formatif dapat menggali kelemahan dan kesulitan belajar siswa, dan dapat memberikan umpan balik pada siswa tentang permasalahan proses pembelajaran serta dapat digunakan sebagai instrumen penilaian keberhasilan proses pembelajaran peserta didik. Dari kesimpulan penelitian di atas secara tidak langsung apabila pembelajaran kooperatif TTS setting nyantrik diberbantukan dengan asesmen formatif bentuk kinerja, secara relevan dapat digunakan sebagai sarana mengukur proses pembelajaran yang dilakukan siswa. Sebagai contoh, apabila diterapkan dalam pembelajaran gambar teknik manufaktur, asesmen formtif memungkinkan untuk menilai proses pembelajaran, menggali permasalahan yang timbul, dan memberikan umpan balik tentang permasalahan pembelajaran yang dihadapi siswa.

Hasil uji kelayakan dan hasil membandingkan rancangan model pembelajaran dengan penelitian yang relevan. Maka dapat ditarik kesimpulan bahwa rancangan model pembelajaran kooperatif TTS setting nyantrik yang telah teruji dan relevan apabila diterapkan dalam pembelajaran di dalam kelas, maka sesuai dengan kesimpulan terhadap pembelajaran ini, pembelajaran kooperatif TTS setting nyantik dengan asesmen formatif bentuk kinerja memungkinkan dapat meningkatkan pemahaman, keterampilan, dan menumbuh kembangkan kearifan budaya lokal dalam memenuhi tuntutan kurikulum yang berlaku saat ini, serta dapat memungkinkan untuk menilai proses pembelajaran, menggali permasalahan yang timbul, dan memberikan umpan balik bagi permasalahan yang ada.

\section{A. Implikasi Penelitian}

Dengan adanya rancangan model pembelajaran kooperatif TTS setting nyantrik ini diharapkan mampu mengatasi permasalahan yang ada di dalam kelas. Sedangkan implementasi asesmen kinerja sebagai alat evaluasi, diharapkan tidak terdapat adanya kecemburuan untuk memberi nilai tinggi atau rendah tetapi memang benar-benar berdasarkan indikator-indikator pencapaian dalam rubrik instrument yang sudah memiliki persyaratan validitas. Maka dengan adanya model pembelajaran kooperatif TTS dan tersedianya instrument penilaian berbasis asesmen kinerja ini dapat membantu guru untuk meningkatkan objekfitas dan intregritas dalam melaksanakan proses pembelajaran dan penilaian siswa secara utuh.

Dalam pelaksanaan penelitian ini, ada beberapa keterbatasan antara lain yaitu, 1) Model pembelajaran yang dikembangkan dalam penelitian ini hanya mencakup validitas dan kepraktisan model pembelajarannya saja. Untuk komponen keefektifan dari model ini tidak dapat direalisasikan mengingat keterbatasan waktu penelitian. 2) Uji coba hanya dilakukan pada sampel kecil, yaitu kelas XI TPm-1 SMK Negeri 3 Singaraja yang berjumlah 30 orang siswa ditambah 1 orang guru model dan 2 orang observer. 3) Tahap uji coba hanya untuk mengetahui keterlaksanaan sintak, sistem sosial, prinsip reaksi, dampak pengiring dan intruksional serta mengetahui respon dari siswa 
terhadap pembelajaran ini dengan cara melakukan observasi.

\section{KESIMPULAN DAN SARAN}

Dalam upaya optimalisasi kompetensi lulusan, penentuan model pembelajaran yang tepat sangat krusial. Memang sudah banyak model pembelajaran yang dikembangkan, namun belum tentu relevan dengan proses pembelajaran di SMK. Penelitian ini mencoba memberi suatu terobosan untuk mengatasi permasalahan tersebut.

Model pembelajaran TTS setting nyantrik yang bersubtansi dengan asesmen formatif bentuk kinerja tentunya menjadi pokok bahasan dalam penelitian ini. Suatu model pembelajaran dapat diterima apabila setiap komponennya memiliki validitas yang tinggi. Dalam pengembangannya, model pembelajaran TTS setting nyantrik dibuat dengan rancangan yang mengadopsi gabungan dari sintak pembelajaran kooperatif, tutor teman sebaya, dan menyisipkan unsur nyantrik dalam proses pembelajaran.

Menilai kualitas model pembelajaran diperlukan instrumen kualitas model pembelajaran. Instrumen tersebut meliputi instrumen kevalidan, kepraktisan dan keefektifan model pembelajaran. Namun pada kesempatan ini, penelitian ini hanya mengadopsi kevalidan dan kepraktisan. Instrumen kevalidan nantinya akan menggukur sintaks, sistem sosial, prinsip reaksi, dan sistem pendukung, dampak pembelajaran dan dampak pengiring yang direalisasikan dalam buku model pembelajaran.

Penelitian ini menggunakan model pengembangan 4-D (Four $D$ ) yang merupakan model pengembangan perangkat pembelajaran. Model pengembangan 4D terdiri atas 4 tahap utama yaitu: Define (Pendefinisian), Design (Perancangan), Develop (Pengembangan) dan Disseminate (Penyebaran). Dalam pelaksanaannya, penelitian ini hanya menggunakan 3 dari 4 tahapan yaitu meliputi 4 tahap yaitu tahap pendefinisian (define), perancangan (design), pengembangan (develop) karena dalam penelitian ini tidak dikembangkan pada skala yang lebih luas, baik di kelas lain, sekolah lain, maupun oleh guru lain. Metode dan model ini dipilih karena bertujuan untuk menghasilkan produk Produk yang dikembangkan kemudian diuji kelayakannya dengan validitas dan uji coba produk untuk mengetahui sejauh mana pembelajaran kooperatif TTS setting nyantrik dapat diterima di sekolah.

Teknik analisis pengembangan dilakukan untuk memperoleh saran oleh ahli atau disebut dengan uji Gregory atau uji Judges atau uji validitas isi atau uji konten. Untuk menetukan koefisien validitas isi, hasil penialaian dari kedua pakar dimasukkan ke dalamtabulasi silang $2 \times 2$ yang terdiri dari kolom A, B, C, dan D. Dari analisis tersebut nantinya akan diketahui tingkat validasi komponen model pembelajaran yang dilakukan. Untuk memberikan makna dan keputusan mengenai respon setelah menggunakan model pembelajaran, pada saat uji coba kepraktisan guru dan siswa dilakukan pengembilan data dalam bentuk angket. Teknik analisis pengembangan angket menggunakan user test, hasil respon dari tiap angket nantinya akan dipresentasekan untuk mengetahui tingkat kepraktisannya.

Hasil validasi oleh para ahli, komponen pembelajaran yang meliputi sintaks, sistem sosial, prinsip reaksi, dan sistem pendukung memperoleh hasil yang relevan untuk diterapkan pada pembelajaran di dalam kelas. Tahap selanjutnya yaitu dengan melakukan uji coba penerapan model guna mengetahui keterlaksanaan komponen pembelajaran tersebut. Tahap uji coba juga dimaksudkan untuk memperoleh data tentang respon dari siswa untuk mengetahui tingkat kepraktisannya. Dari hasil uji coba, keterlaksanaan sintak model pembelajaran dapat terealisasi semua dalam tiga kali pertemuan. Hasil angket kepraktisan guru memperoleh kesimpulan sangat praktis dan siswa memperoleh kesimpulan praktis

Dari data hasil validitas, uji coba dan rujukan dari penelitian yang relevan dapat disimpulkan model pembelajaran kooperatif TTS setting nyantrik dengan asesmen 
formatif bentuk kinerja memiliki yang dikembangkan memiliki sintak yang meliputi tujuan dan motivasi, informasi materi, mengorgansasi siswa ke dalam kelompokkelompok belajar, diskusi kelompok secara nyantrik, laporan kelompok, penghargaan, kesimpulan pembelajaran, tes/evaluasi pembelajaran. Model pembelajaran ini dikatakan valid dan praktis apabila diterapkan dalam proses pembelajaran.

Berdasarkan pertanyaan penelitian dan hasil penelitian yang telah diuraikan, diperoleh kesimpulan sebagai berikut:

1. Pengembangan model pembelajaran kooperatif TTS setting nyantrik menghasilkan beberapa tahapan sintak yang meliputi tujuan dan motivasi, informasi materi, mengorgansasi siswa ke dalam kelompok-kelompok belajar, diskusi kelompok secara nyantrik, laporan kelompok, penghargaan, kesimpulan pembelajaran, tes/evaluasi pembelajaran

2. Hasil validasi dan uji coba seluruh aspek pengembangan model pembelajaran ini dapat disimpulkan relevan apabila diterapkan.

Berdasarkan kesimpulan yang dikemukakan di atas, beberapa saran yang perlu dipertimbangkan untuk peningkatan kualitas pembelajaran kooperatif TTS setting nyantrik pada mata pelajaran teknik gambar manufaktur saat diterapkan di sekolah sebagai berikut:

1. Bagi guru SMK, disarankan untuk memanfaatkan produk pembelajaran yang dikembangkan sebagai salah satu pembelajaran kooperatifyang diharapkan mampu menstimulasi kemampuan peserta didik dalam bekerja secara kelompok

2. Pelaksanaan pembelajaran kooperatif TTS setting nyantrik dalam matapelajaran teknik gambar manufaktur di sekolah hendaknya senantiasa disesuaikan dan didasarkan pada kurikulum yang telah ditentukan oleh Pemerintah.

3. penulis menyadari bahwa penelitian ini masih bersifat sederhana, dimana perancangan dan implementasi model pembelajaran kooperatif TTS setting nyantrik dengan asesmen formatif kinerja ini dilakukan hanya pada mata pelajaran teknik gambar manufaktur. Oleh karena itu secara lebih luas penelitian model ini perlu dikembangkan pada bidang keahlian yang lain dengan jumlah sampel yang lebih banyak serta dengan kreteria rubrik dan pembobotan penyekoran yang lebih relevan, sehingga instrument dalam bentuk asesmen kinerja yang dikembangkan dapat memenuhi syarat validitas yang lebih signifikan.

\section{UCAPAN TERIMAKASIH}

Ucapan terima kasih, penulis sampaikan kepada :

1. Dr. I Nyoman Jampel, M.Pd, selaku Rektor Universitas Pendidikan Ganesha Singaraja yang telah memberikan bantuan secara moral dan memfasilitasi berbagai kepentingan studi, selama penulis menempuh perkuliahan di Program Pascasarjana.

2. Prof. Dr. I Wayan Suastra, M.Pd, selaku Direktur Program Pascasarjana Universitas Pendidikan Ganesha Singaraja dan staf, yang telah banyak membantu selama penulis mengikuti studi dan menyelesaikan penulisan proposal tesis ini.

3. Dr. Ni Ketut Widiartini, M.Pd, selaku Ketua Program Studi Penelitian dan Evaluasi Pendidikan beserta staf dosen pengajar yang telah banyak membantu dan memotivasi penulis selama perjalanan studi dan penyusunan proposal ini.

4. Prof. Dr. Made Candiasa, M.I.Komp., selaku Pembimbing I yang telah membimbing dengan penuh kesabaran, kecermatan, dan ketelitian di tengah-tengah kesibukan beliau dan memberikan motivasi, arahan, saran dan kritik kepada penulis, semenjak awal penyusunan hingga selesainya proposal tesis ini.

5. Dr. I Gede Sudiartha, M.Pd, selaku Pembimbing II yang telah membimbing dengan penuh kesabaran, kecermatan, dan ketelitian di tengah-tengah kesibukan beliau dan memberikan 
motivasi, arahan, saran dan kritik kepada penulis, semenjak awal penyusunan hingga selesainya proposal tesis ini.

6. Bapak Drs. I Nyoman Suastika, M.Pd, selaku Kepala SMK Negeri 3 Singaraja yang telah memberikan dukungan moril dan materil yang menumbuhkan semangat serta ijin tempat untuk melaksanakan penelitian dengan nomor : 1259/UN48.14/KM/2017.

\section{DAFTAR RUJUKAN}

Aria, Djalil., dkk. 1997. Pembelajaran Kelas Rangkap. Jakarta : Depdikbud.

Arikunto, S. 1986. Prosedur Penelitian Suatu Pendekatan Praktik. Jakarta : Bina Aksara.

Depdiknas. 2003. Standar Kompetensi Mata Pelajaran Kimia Sekolah Menengah dan Madrasah Aliyah. Jakarta : Depdiknas.

Haryono. 2016. "Nyantrik Learning Model in the Field Experience Practice Program for The Bachelor (S-1) Workforce Education Institutions". Jawa Timur, Indonesia: PGRI Ngawi.

Jaelani, Aceng. 2013. Penelitian dengan judul "Pembelajaran Kooperatif, Sebagai Salah Satu Model Pembelajaran Di Madrasah Ibtidaiyya". Jurnal Penelitian. Cirebon : PGMI FITK IAIN Syekh Nurjati

Putranti, Nurita. 2007. Tutor Sebaya. Tersedia pada http:www.nuritaputranti.wordpress.com (diakses tanggal 25/10/2017).

Suprijono, Agus. (2009). Cooperative Learning. Yogyakarta: Pustaka Pelajar.

Subini, Nini. 2012. Psikologi Pembelajaran. Yogyakarta: Mentari Pustaka.

Sardjiyo dan Pannen. 2005. Pembelajaran Berbasis Budaya. Jurnal Pendidikan, Volume 6, No. 2 (hlm. 83-98).

Slavin. (2005). Cooperative Learning. Bandung: Nusa Media.

Sukawijana. 2015. Perancangan dan Implementasi Asesmen Kinerja pada Mata Pelajaran Perakitan Komputer di Kelas $X$ Teknik Komputer Jaringan SMK Negeri 3 Singaraja. Tesis. Program Pasca Sarjana Undiksha Singaraja.
Tastra, I Ketut., dkk. 2013. Pengaruh Penggunaan Model Pembelajaran Kooperatif Tipe Jigsaw Terhadap Hasil Belajar Menulis Ditinjau dari Motivasi Berprestasi Siswa Kelas VII SMP Negeri 4 Mendoyo. Singaraja: Universitas Pendidikan Ganesha. Vol. 3

Wahyu Hidayat, Adib. 2013. Penerapan Metode Tutor Sebaya Pada Mata Diklat Autocad Di SMK Negeri 3 Semarang Program Keahlian Gambar Bangunan. Jawa Tengah: Universitas Negeri Semarang 